\title{
朝鮮時代の儒学者・尹善道に係わる庭園の構成とその 特徵
}

\section{Studies on the Spatial Composition and the Characteristics of Yun Seun-do's Garden}

金 眞成 ${ }^{*}$ 藤井英二郎 ${ }^{* *}$

Jin-seung KIM Eijiro FUJII

\begin{abstract}
摘要：朝鮮時代中期の儒学者・尹善道が造営したいくつかの庭園遺構について現況測量や史料をもと にその構成を比較し、その背景にある思想とその推移について考察した。最初の隠遁地・芙蓉洞の庭 園は治世のあり方を示す強い姿勢がみられるものであった。その 4 年後に築いた金鎖洞の居処・會心 堂は山頂部に位置し，実社会との関わりは薄くなる。しかし，一貫して教育の場が設けられていた点 はその隱遁にみられる特徵である。こうした㩊遁のあり方は儒教思想が根強い朝鮮の隱遁の特徵を示 すものであり，儒教の捉え方に違いはあるものの中国と類似するものと言えよう。しかし，それは日 本でみられた㩊遁とは大きく異なるものと言える。
\end{abstract}

\section{1. 序}

韓国の朝鮮時代は儒教を政治の規範とし，それは生活にも深く 及んでいた。その時代の庭園にみられる儒教の影響については 鄭 ${ }^{1)}$, 白ら ${ }^{2)}$ の研究があるが, 当時しばしばみられた隠遁生活と 庭園との関わりについての議論は少ない。

本研究は韓・日両国の庭園に見られる儒教の影響を比較するこ とを視野に入れながら, 韓国・朝鮮時代の庭園構成の特徴を明ら かにしようとするものである。具体的には，江戸時代初期から中 期に相当する朝鮮時代中期の代表的な儒学者であり詩人でもある 尹善道(1587-1671)の庭園に着目した。

尹善道の庭園遺構としては，先祖代々の海南尹氏 ${ }^{32}$ の本居であ る海南蓮洞 ${ }^{4}$ (韓国全羅南道海南郡) をはじめ, 清の侵略を受け た後に築いた甫吉島（全羅南道莞島郡）の別業である芙蓉洞，そ して隠遁を決意してから築いた海南の水晶洞・聞簫洞・金鎖洞な どがあげられる（図1）。

尹善道に関わる庭園については，これまでいくつかの研究がな されている。甫吉島の別業については，莞島郡庁が現況を測量す ると同時に樂書齋・洞天石室・洗然亭の位置を推定した ${ }^{5)}$ 。次い

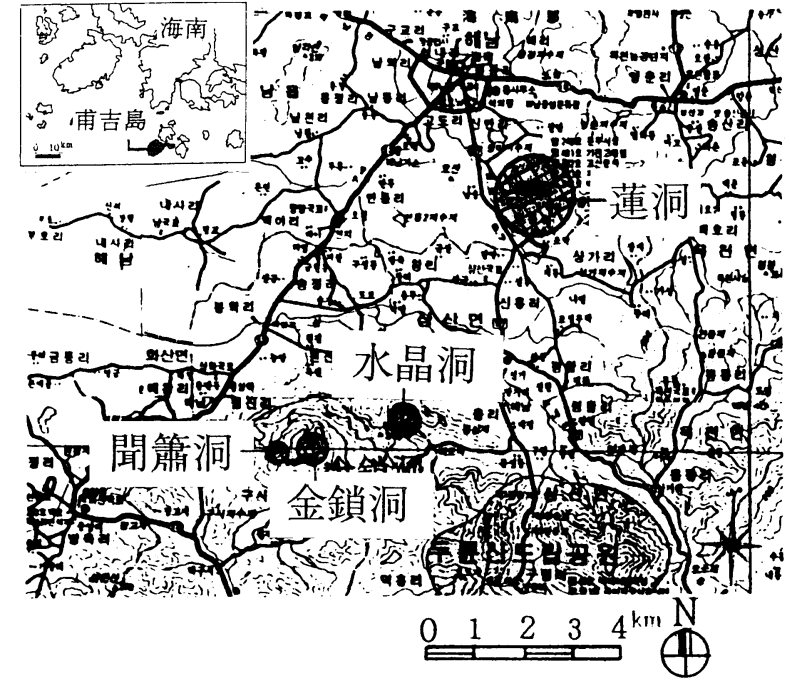

図-1 尹善道に係わる庭園遺構の位置
で鄭はその報告書をもとに『孤山先生年譜』の検討を行い，芙蓉 洞の庭園構成を，樂書齊がある郎吟溪之，洞天石室，洗然亭の 3 区域に分けた。そして，それら全体の構成は景勝地に庭園建築を 点在させた隠遁のための園林であるとした ${ }^{6)} 。$

既往の研究は芙蓉洞についてのみであり，その他の別業につい ては検討されていない。尹善道の庭園遗構は，蓮洞の住まいを除 いて，いずれ屯現在秏蒼とした樹林に覆われており，往時の姿を 容易に挆ることはできない。そこで関係者の許可を得て，1995 年から 97 年にかけて，芙蓉洞をはじめ，水晶洞，金鎖洞などの 遗構を覆った樹木を整理し，現況測量を実施した。芙蓉洞 ${ }^{7}$ ，水 晶洞 ${ }^{8)}$ ，そして金鎖洞 $\left.{ }^{9}\right)$ の各々の空間構成についてはすでに報告 した。本報ではこうした検討結果を踏まえ，それぞれの庭園の特 徵を比較しながら，その背景をなす孤山の思想とその推移につい て考察する。

\section{2. 甫吉島に営まれた芙蓉洞の構成}

島の主峰加発するもっとも大きな谷に孤山は芙蓉洞と名付け た ${ }^{10)}$ (四 2)。それは，その地形が半開した蓮のような形をして いることによるものである。孤山はまた，そこを中国・宋時代の 儒学者であり，孤山が真の隠者として崇めた朱子の住まいである 建陽の雲谷に準え, 神仙が住む蓬㽦や蓬莱として捉えていた ${ }^{11)}$ 。

\section{(1) 樂書齋}

孤山が居所として築いた樂書齋は芙蓉洞の南端に位置する山容 穏やかな主峯から発する尾根の流れを背負うところに位置するこ

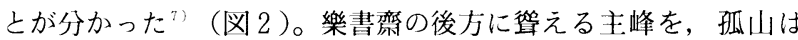
朱子の居処であった紫陽書院に因んで「格紫害」と名付けた。樂 書齋の左右には格紫菨から発する小さな尾根がのび，樂書齋の左 右前方の空間を限っている。

樂書齊のこの立地は格紫峯から尾根伝いに流れる気を受け止め, その気が止まる場所，即ち「明堂」(2) に当たる。気脈を受けるこ とを優先した風水論的な立地選定は，樂書齋の向きが結果として 日照条件の悪い北向きになっていたことからも首肯できる。

さらに樂書齋空間の詳細をみると, 前庭に格紫峯からの水を導 き入れた大槽を配した ${ }^{10)}$ とされる。気は水によって止まるとされ ることから，この水槽は格紫峯からの気を止める積極的な意味を 持っていたものと考えられる。また，樂書齋の背後には朱子の大 隠屏に倣って小隠屏と名付けた大岩があり，その大岩の前方は風

\footnotetext{
*千葉大学大学院自然科学研究科 *千葉大学園芸学部緑地・環境学科
} 


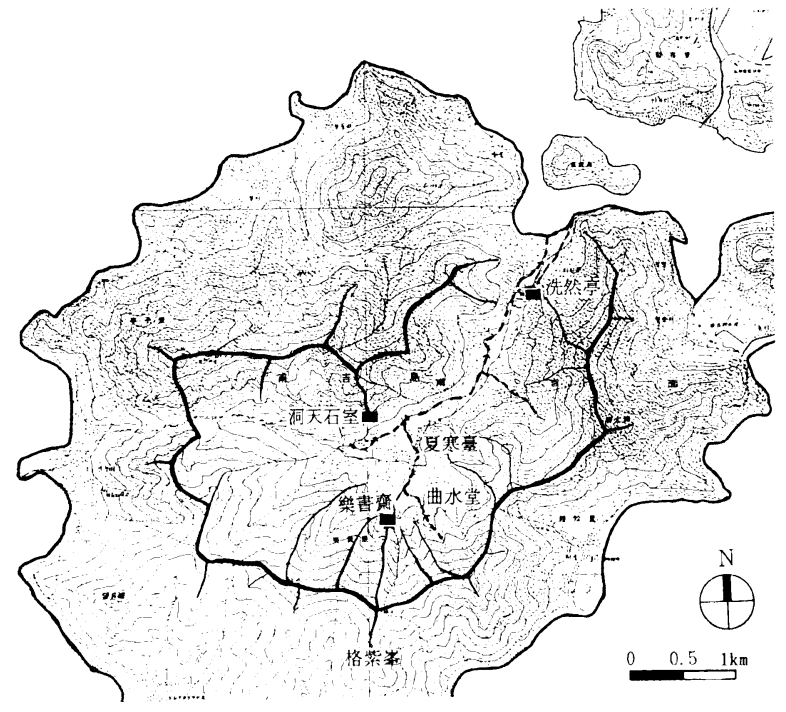

図一２甫吉島に営まれた芙蓉洞の空間構成

水論でいう気が集結する「穴」(3)に当たる。

このように樂费齋の立地とその空間構成は, 風水論に基づくと 同時に朱子の影響を強く受けていたことが分かる。

樂書齋の東側近くには教育機関としての書室や静成㟟が建てら れていた ${ }^{1014)}$ 。芙蓉洞は孤山が隠遁を決意して営んだ空間である にも拘わらず，そこに教育の場を設けていたことが特徽的である。

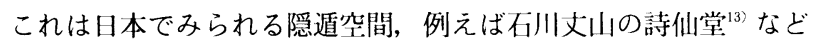
とは大きく異なる特徴と言えよう。つまり，丈山には現世を厭う 姿勢がみられ, 風雅の道に没頭しこそすれ, 教育などを通して現 世を正だそうとする姿は見られなかった 。

樂書齋の前方・北側の谷・郎吟渓を挟んで格紫峯と対峙する山 を風水上の案山吾 とし, 孤山はその山腰・露岩が岩山を呈したと ころに，仙人の住まいとして「洞天石室」を築いた ${ }^{10)}$ (図 3 )。 この仙人の住まいを孤山の住居である樂書齊の前方, 谷を隔てた 山の山腹に配置したところに後述する金鎖洞とは異なる特徴をみ いだすことができる。つまり，仙人と孤山の住まいの間に大きな 空間的隔たりがあるのである。

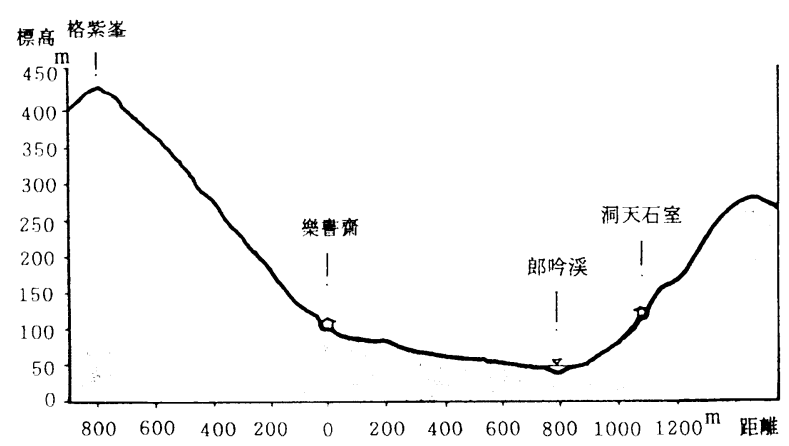

図-3 孤山の居所・樂書齋と洞天石室の位置

\section{（2）洗然亭}

洗然亭は格紫峯を源にする流れ・郎吟渓の河口近く，その分水 をせき止めて造成した池中の中島に位置する（図 2 )。この洗然 亭は, 孤山が「洗然繁華而兼清整廊廟之器也」 ${ }^{18)}$ としていること から，そこは清らかに賑わう人々の生活を見る場であり，それは また太平聖代の世を待つ孤山の治世のあり方を示す場でああった と考えられる。

こうした孤山の姿勢は, 洗然亭を取り用む水が水田の用水とし

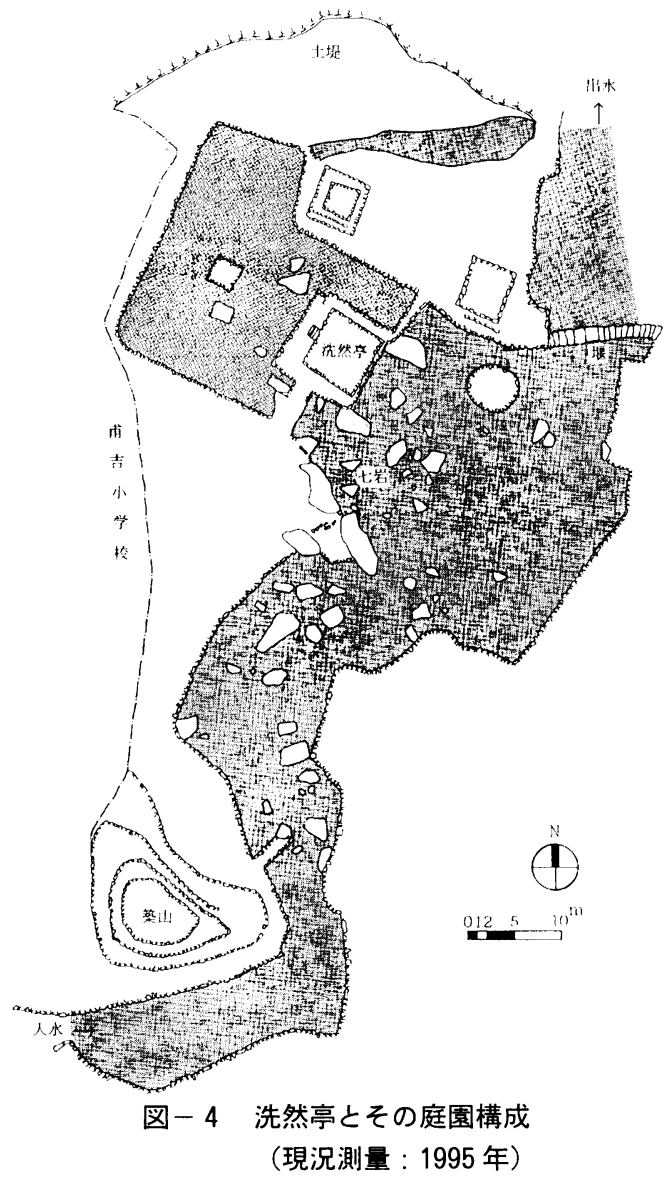

て使われていたことに具体的にみることができる。すなわち，洗 然亭の池水はその北東側に現存する, 一辺が $2 \mathrm{~m}$ にあ及ぶ多くの 扁平な大石によって造られた堰によって成るものであり（図 4 ）, その池水が東北端から流れ出て郎吟渓本流に合流し，その下流に 広がる水田用水として使われていたと推定された は洗然亭を取り囲む園池を形づくるとともに，その下手に位置す る水田用水の貯溜と水量調節を計るものであったと判断できる。 洗然亭の南東側の池には大きな七つの岩・「七岩」が現存し, その内の一つに孤山は「或躍」と名付けている ${ }^{10)}$ 。これは臥龍に 比喻される ${ }^{\mid 97}$ もので, 志を持った儒者が活躍できる時代の到来を 待つ意味がある。これは，この芙蓉洞に身を置く孤山の立場を端 的に示すむのであり, 朝鮮における隠遁の特徴の一つを示すむの と言える。すなわち, 朝鮮における隠遁は時の政治から離れるこ とであり, 決して実社会から離れるものではない。

以上にみるように，周用を山容穞やかな稜線に井まれた谷・芙 蓉洞とその要所に配された樂書齊, 洞天石室, 洗然亭の構成は, 鄭 ${ }^{6)}$ が指摘したように景勝地に庭園建築を点在させた園林という ことができる。そして, その具体的な配置と構成, さらには背景 を探ると，そこには風水論とともに，孤山が崇拝した朱子の影響 を色濃く見ることができた。さらに水田と深く係わる園池の在り 様は，政治が人々に繁栄をもたらす具体例とも言え，そこには治 世のあるべき姿を主張する孤山の姿勢をみることができる。この 姿勢は, 隠遁の住まい近くに教育の場を設けたことと合わせて, その隠遁の特徴ということができる。

\section{3. 金鎖洞の空間構成}

孤山自らが記した『金鎖洞記』をもとに金鎖洞の位置を推定し， そこにみられた建物遺構を中心に測量した結果, 孤山が住まいと 
した會心堂は緩やかな傾斜地が広がる山上に位置することが分かっ た ${ }^{9)}$ 。金鎖洞の空間は山裾を流れる川を渡り，急峻な斜面を経て 大きな滝に至る空間と，滝の上部に広がる緩やかな傾斜を持つ山 頂部の空間に分けられる ${ }^{9)}$ 。その山上の空間を孤山は神仙が住む 「上清」とし，別世界・桃源としてとらえ，その中に常の住まい・ 會心堂を営んでいた。一方, 山裾の川から滰に至る経路には孤山 が命名した様々な景物が点在し，そこには隠遁に至る孤山の強い 意志を読みとることができた ${ }^{9)}$ 。

\section{(1) 會心堂}

山上の空間には高麗時代の築造ともされる山城跡が残り，會心 堂はその中に位置する（図 5 )。山上部を構成する頂の中でもっ とも高い南側の山から発する尾根の流れの未端に大きな岩の露頭 があり，その岩の前面・平坦地に北面する形で會心堂が営まれて いた。會心堂の左手・西側には上述の滰の水源になる流れがあり, その向こう側には山頂部の北側を限る低い尾根を望むことができ る。この景色に孤山は朱子の雲谷草堂の右手に広がる光景を重稀 ている ${ }^{20)}$ 。従って, 會心堂の立地選定にもまた樂書齋と同じく風 水論とともに朱子の影響が指摘できる。

會心堂の西から北東にのびる尾根の北東端, 會心堂から $300 \mathrm{~m}$ 程離れた一角には大きな岩の露頭が連なる特異な景観がみられる。 孤山はこの光景に神仙の世界・「上清」を見いだし，幾つかの岩

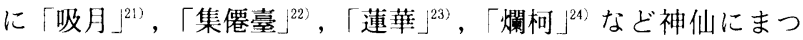
わる命名をしていた ${ }^{20)}$ (図 5 )。この神仙世界は孤山の居処・會 心堂加ほど近い山頂部に位置する（図6)。神仙世界之孤山の 居処にみるこの位置関係は，前述の芙蓉洞でみた樂書齋と洞天石 室の関係とは大きく異なる。つまり，芙蓉洞では孤山の居処之神 仙世界とが谷を隔てて位置していたのに対して，この金鎖洞では それらがともに緩やかな起伏をもつ山上に位置している。

芙蓉洞と金鎖洞は僅か 4 年の月日を隔て構成されたものではあ るが，上述の構成にみられる大きな違いからこの間に孤山の心境 は大きく変化したものと考えられる。つまり，芙蓉洞の構成には 現世への強い拘りと同時に神仙世界とは距離を圆いた立地選定が みられるのに対して，金鎖洞では実社会に対する拘りから解放さ れ，神仙世界に近接する立地選定をみることができると言えよう。 會心堂周りにはさらに儒者のあり方を示す構成もみられる。つ

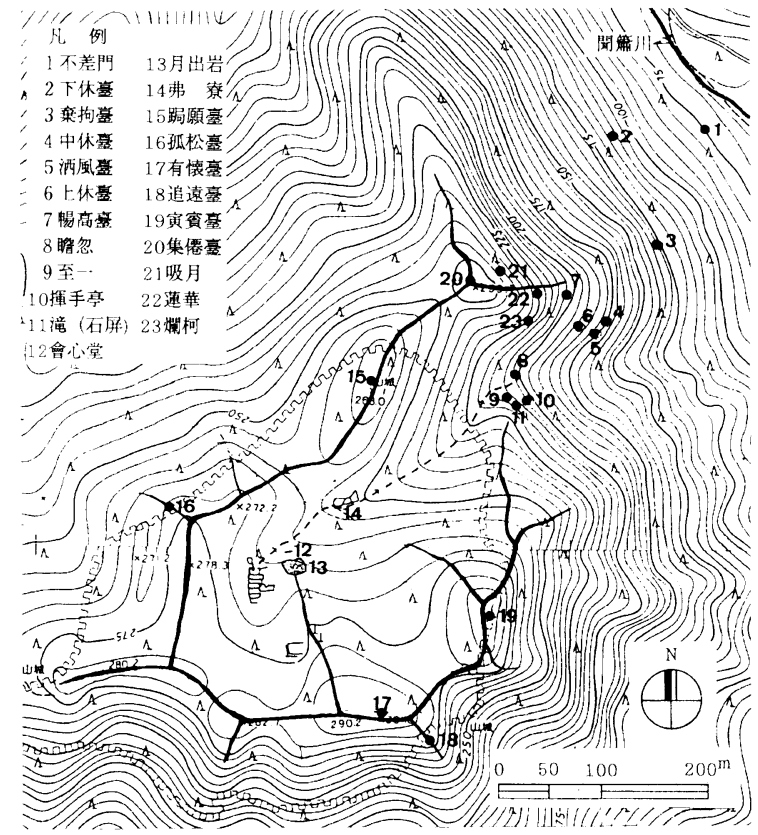

図－5 金鎖洞の空間構成（現況測量 : 1997 年）

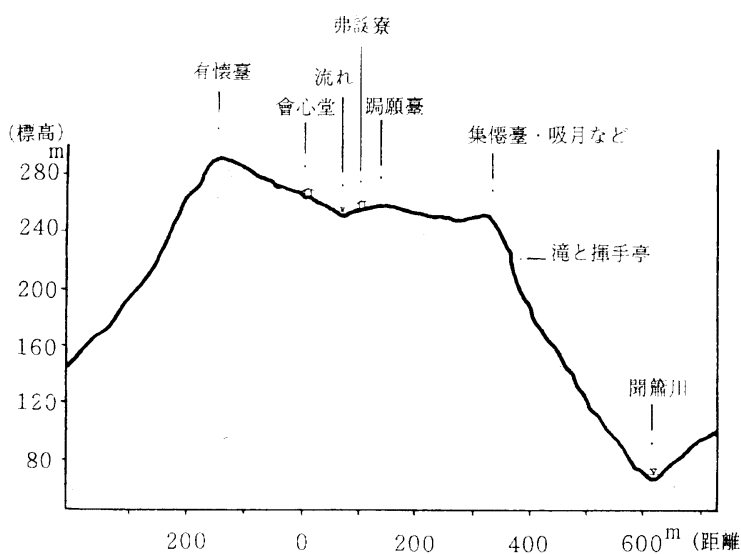

図ー6 金鎖洞における山裾から滝までの空間と滝の上部に広が る會心堂を中心とした空間

まり，孤山は會心堂を取り囲む四方の峯に先人を想い起こす「有 懐喜」 ${ }^{25)}$ ，「追遠臺 ${ }^{26)}$ ，さらに日月を望むところとして「寅賓 ${ }^{277}$, 王を扯するところとして「跼願 (28) などを名付けた201。これらは 現世之の関わりを断ち切らない隠遁の姿を示すものであり，孤山 の隠遁の特徵と言えよう。このような隠遁は, 儒教を政治の指導 原理とする官僚世界を世俗とし，その世俗から離れることを隠遁 之する中国 ${ }^{29}$ と類似するが, 儒教思想がより強く現れている点に 朝鮮の隠遁の特徴をみることができる。

會心堂の周辺には後学の居処である「教義齊」が建てられてい たとされる ${ }^{303}$ 。家督を譲り，隠遁を表明してから営んだ隠遁地で ある金鎖洞にも教育の場が設けられていたことは孤山の教育に対 する一貫した姿勢であり，これは彼の隠遁にみられる大きな特徴 と言えよう。

\section{(2) 揮手亭}

山裾を流れる川を西に渡り，急峻な山道を登ると所々に大きな 岩の露頭があり，それらを経ると大きな滰に突き当たり，その下・ 前方に揮手亭の基壇遗構を見いだすことができた ${ }^{9}$ （図 5 )。

この揮手亭に至るまでの景物に付与した孤山の命名には隠遁に 至る孤山の心の動きがよく現れている ${ }^{97}$ 。川を渡ってまもなく現 れる道を塞ぐような大きな岩に「不差門」品立名付けた。それは 自らの選択を確信し，隠遁の決意を示すものである。さらに登る と，拘りを捨てるという意味で名付けられた「菓拘臺」があり， さらにその上方には「中休臺」，また世の中に対する未練が解消 することを示す「暢高臺」がある。さらに登ると心地よい風を受

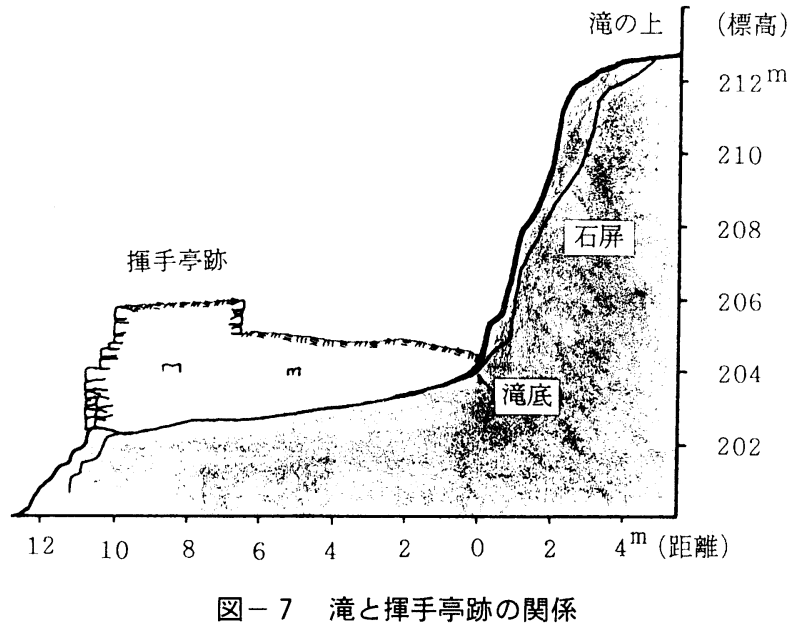


けるとの意味を持つ「酒風臺」，さらには思わず仰ぎみる意味の 「瞊忽」がある。これは迷いを断ち切る閃光にさらされるような 意味合いを持っていたものと考えられる。さらにその先には道は 一つ言う意味の「至一」があり，その前方に滰が現れる。ここ で言う道は朱子学の基本理念の一つである性 ${ }^{32)}$ であった ${ }^{33)}$ 。

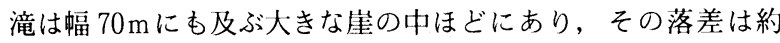
$9 \mathrm{~m}$ である。前述した揮手亭の基壇は, その前面・東側の平坦地 の東端に位置する（図 7 )。揮手とは人家から離れ自分の世界に 入ることを意味することから，孤山はこの空間を滰の上部に展開 する別天地と，その下部に展開する現世とを区切る結界と位置づ けているあのと考えられる。

\section{4. 結論}

芙蓉洞では格紫峯の北麓, 小隠屏と名付けられた大岩の下・北 側に樂書齊を建て，また金鎖洞では月出岩と名付けられた大岩の 下・北側に會心堂を建てた。これらの建物はいずれも後方に位置 する主山の気脈を受ける形になっており，北面していた。このよ うな建物配置は方位よりも気脈を受けることを重視する風水論に 基づくものであると言える。

これらの空間にはさらに朱子の影響もみられた。芙蓉洞を朱子 が住んだ雲谷とし，その主峰・格紫峯は朱子の紫陽書院に因んで 名付けられたものであった。一方，金鎖洞では會心堂の左手に展 開する景色に雲谷の右手に広がる景色を重ねていた。

孤山の最初の隠遁地であった芙蓉洞は, 甫吉島の主峰から発す る大きな谷に位置し，そこに営まれた庭園は実社会と深く係わる
あのであった。つまり，洗然亭には治世のあり方を示す意図が込 められ，またその周囲を取り用む園池は水田耕作と深く係わるも のであった。それに対して，その 4 年後に営まれた金鎖洞の居処・ 會心堂は人家とは遠く隔てた山上部に構成され，そこでは治世の あり方を示す姿勢や水田耕作との関わりはみられなかった。

また，芙蓉洞では神仙世界が孤山の居処・樂書齊から谷を隔て て位置づけられていたのに対して，金鎖洞ではその居処・會心堂 とひとつらなりの空間に位置づけられていた。従って，金鎖洞て は神仙世界により近づいた孤山の心境がみられるととあに，隠遁 姿勢の変化を読みとることができる。つまり，治世のあるべき姿 を具体的に示す隠遁から，政治を正だそうとする拘りから解放さ れた隠遁への変化である。しかし，芙蓉洞と金鎖洞のいずれにお いても教育の場が設けられていたのであり，この点に孤山の隠遁 にみられる一貫した特徵が指摘できる。こうした隠遁のあり方は 儒教思想が根強い朝鮮の隠遁の特徽を示すむのであり, 儒教の捉 え方に違いはあるものの中国の隠遁之類似するものと言えよう。 しかし，これは政治や教育などの日常生活との関係を絶とうとす る日本の隠遁のあり方 ${ }^{34)}$ とは大きく異なるものと言える。

謝辞 : この論文に係わる調査, 検討に際して, 様々に便宣を図っ て戴いた尹享植氏 (尹善道の 11 代孫), 現況調査を共にした白志 星氏 (全南大学助教授), 金恩一氏 (全南大学専任講師), 全南大 学の学生諸氏, そして張美娥氏 (千葉大学環境植栽学研究室) に 感謝する。さらに本論の考察において助言を戴いた浅野二郎氏 （千葉大学名誉教授）に謝意を表したい。

\section{補注及び引用文献}

1) 鄭朣旿（1986）：韓国の庭園：民音社, ソウ ル, $319 \mathrm{pp}$.

2 ) 白志星・藤井英二郎・仲隆裕・浅野二郎 (1992)：韓国・朝鮮時代の東闒における庭 園植栽について一昌徳宮の外朝及び治朝 : 千葉大園芸学部学術報告 46,203-213

3 ）海南尹氏：全羅南道に位㯰する海南を本貫 すなわち，本籍地・本とする尹氏。

4 ）金畺成・鄭朣旪 (1993)：造景学的側面から みた韓国伝統村の屋外空間構成に関する研 究 : 韓国庭苑学会誌 11(1),69-88

5 ) 莞島郡 (1981)：甫吉島尹孤山遺跡調査報告 書 : $104 \mathrm{pp}$.

6 ) 鄭朣旿 (1986)：前出：227-241

7 ) 金眞成・藤井英二郎・白志星（1997）：朝鮮 時代の儒学者・尹善道の甫吉岛芙容洞庭園 に関する研究: 千葉大園芸学部学術報告 52 , 印刷中

8 ) 金眞成, 白志星, 藤井英二郎, 金恩一（19 96)：孤山・尹善道の海南水晶洞庭園の空間 構成に関する研究（I）：韓国庭苑学会誌 $14(2), 214-222$

9 ）金畺成・藤井英二郎・白志星・金恩一（19 97）：韓国・朝鮮時代の儒学者・尹善道にみ
る隠遁の姿一日本との比較を視野に入れな がら: 平成 9 年度日本庭園学会研究大会発 表要旨集, 6-9

10）尹愇（1748）：甫吉易識：尹毫植氏所蔵，海 南

11）徐鼎修（1798）：孤山遺稿：巻之一三十四, 詩, 「黄原雑詠三首」, 尹亭植氏所蔵, 海南

12）崔昌栃（1986）：韓国の風水思想：民音社, ソウル, $62-64$

13）崔昌秨 (1986)：前出，56-57，125

14）尹觀夏（1878）：孤山先生年譜：尹毫植氏所 蔵, 海南

15) 石川琢堂 (1961) : 詩仙堂 : 便利堂, $32 \mathrm{pp}$.

16）林羅山（1643）：詩仙堂記（石川玩堂（1961）: 前出, $27-29$ 上り)

17）崔昌秨（1986）：前出：62．穴の前にある 朝山より低くて小さい山。

18）井愇（1748）：前出：洗然繁華而兼清整榔潮 之器也：洗然は繁華しながら清整を兼ねて いることから朝廷で天下の政治を行うこと ができる才能すなわち, 廊廟之器がある。

19）徐鼎修 (1798)：前出：巻之 三十三 詩, 或踓嚴

20）尹善道（1641）：金鎖洞記：尹敦植氏所蔵, 海南
21）吸月：天端が平らな石臺を仙人が集う場と して見立て吸月とする。『金鎖洞記』より

22）集僊臺 : 多くの仙人が道を講じる様子に見 立てる。同上

23）蓮華臺：蓮のつぼみが開いたような尖った 石角の样子から見立てる。同上

24）軖柯：仙人が基盤に向かう故事に做ったも ので，碁に夢中になって時の経つのも忘れ ることを爛柯（斧の柄が腐ること）という ようになった。石川忠久（1984）: 中国古典 詩聚花 : 小学館, 184-185

25）有懐：二人の意に懐かしさがある

26）追遠 : 祖先を想い浮かべる

27）宙賓：尊敬して導く

28）跼願：かがんで願う

29）小尾郊一－（1995）: 中国の隠遁思想：中央公 論社, $193 \mathrm{pp}$.

30）尹觀夏（1878）：前出：巻之一十六

31）不差：間違いないという意味

32）尹善道（1641）：前出：性之反之及其至也則 一也から「至一」と名付ける。

33）朱子が集註した『小学集註』の立教第一に 「天命之謂性」とあり，性は天命であり，そ の性はまた「理」であると解釈している。

34）小尾郊一 (1995)：前出：i

Summary : Based on the survey of present situation and the analysis of related historical literature, we studied the spatial composition of Puyongdong and Gumseidong gardens, constructed by Yun Seun-do(Kosan), an outstanding confucian in Chosen period, who spent a secluded life for many years in both areas. These spatial composition are considered to be fundamentally based on the two ideas; Pungsu theory and the doctrines of Zhuzi. Puyongdong, his first seclusion area, is located in a big valley of Bogil island. We could find out his ideals showing the idea of politics. On the contrary, Hoeshimdang of Gumseidong which was constructed in about 4 years later in the upper area of a mountain the relation with the real world becomes thin. These characteristics are deep-rooted in Confucianism, as in Chinese seclusion. But, it is quite different from seclusion in Japan. 